\title{
A comparative study between fine needle aspiration biopsy (FNAB) findings and histopathology in the evaluation of canine skin and skin adnexal tumors"
}

\author{
Nihat YUMUŞAK ${ }^{1}$, Osman KUTSAL ${ }^{2}$ \\ ${ }^{1}$ Harran University, Faculty of Veterinary Medicine, Department of Pathology, Şanlıurfa; ${ }^{2}$ Ankara University, Faculty of Veterinary \\ Medicine, Department of Pathology, Ankara, Turkey.
}

Summary: The material of this study was, cytopathologic and histopathologic specimens obtained from 43 of dogs suffering from skin tumors. Samples were submitted by Ankara University, Faculty of Veterinary Medicine or private clinics of veterinary in Ankara. Cytologic specimens were prepared by fine needle aspiration biopsy (FNAB) technique and stained with May-Grünwald Giemsa (MGG). For histopathologic examinations tissue samples were obtained by surgery. Samples were fixed in $10 \%$ neutral formalin solution and embedded in paraffin by routine procedures and stained with Hematoxylin-Eosin (H\&E). Tumors were obtained from 29 male dogs and 14 female dogs. The age with highest incidence in dogs was between 8 and 15 . The breeds of dogs more frequently affected were 14 terrier, 14 mongrel and 15 another different breeds. Localizations of tumors were in the followed regions, head, perianal regions and legs. Cytopathologically, 30 (69,76\%) malignant epithelial tumors, $5(11,62 \%)$ benign epithelial tumors, $6(13,95 \%)$ suspect epithelial tumors and $2(4,65 \%)$ few malignant epithelial tumors were diagnosed. Histopathological diagnosis determined $12(27,9 \%)$ squoamous cell carcinoma, 9 (20,9\%) hepatoid gland tumours, 7 (16,3\%) basal cell carcinoma, 7 $(16,3 \%)$ sweat gland tumours, $5(11,6 \%)$ sebaceous gland tumours, $2(4,7 \%)$ papilloma and $1(2,3 \%)$ malignant pilomatricoma. The diagnoses were in agreement cytopathologically and histopathologically in $86,05 \%$ of cases. The results obtained in the present study suggest that cytopathology is a practical tool for the early diagnosis of canine skin tumours.

Keywords: Cytopathology, dog, fine needle aspiration biopsy, histopathology, skin tumours.

\section{Köpeklerde deri ve eklenti tümörlerinin değerlendirilmesinde ince iğne aspirasyon biyopsisi (ï̇AB) bulgularının histopatolojik bulgularla karşılaştırılması}

\begin{abstract}
Özet: Bu çalışmada, Ankara Üniversitesi Veteriner Fakültesi’ne ve Ankara'da bulunan özel veteriner kliniklerine deri tümörü şüphesiyle getirilen 43 köpeğe ait biyopsi örneği sitopatolojik ve histopatolojik olarak incelendi. Sitopatolojik örnekler sedasyon altında ince iğne aspirasyon biyopsisi (İ̈AB) tekniği ile alınarak May-Grünwald Giemsa (MGG) ile boyandı. Histopatolojik inceleme amacıyla alınan doku örnekleri \%10'luk nötral formalin solüsyonunda tespit edilip, rutin doku takibine alınarak hematoksilen-eozin (H\&E) ile boyandı. Tümörlerin alındığı köpeklerden 29'u erkek olup 14'ü ise dişiydi. Tümör görülme oranının 8-15 yaşları arasında arttı̆̆ gözlendi. Köpek ırkları incelendiğinde; köpeklerden 14'ü terrier, 14'ü melez ve 15'i diğer ırklardandı. Lokalizasyon olarak tümörler daha çok kafa, perianal bölge ve ön-arka bacaklarda yerleşim göstermekteydi. Sitopatolojik olarak toplam tümörlerden 30 $(\% 69,76)$ 'una malign epitelyal tümör, $5(\% 11,62)$ 'ine benign epitelyal tümör, $6(\% 13,95)$ 'sına epitelyal tümör şüpheli ve 2 $(\% 4,65)$ 'sine hafif malign epitelyal tümör tanısı konuldu. Histopatolojik olarak yapılan tanılar doğrultusunda ise tespit edilen tümörler; $12(\% 27,9)$ yassı hücreli kanser, $9(\% 20,9)$ hepatoid bez tümörü, $7(\% 16,3)$ bazal hücreli kanser, $7(\% 16,3)$ ter bezi tümörü, $5(\% 11,6)$ sebaseöz bez tümörü, 2 (\% 4,7) papillom ve $1(\% 2,3)$ malignant pilomatrikom olarak belirlendi. Çalışma sonucunda sitopatolojik ve histopatolojik olarak yapılan tanıların karşılaştırmasında \%86,05 oranında her iki tanının birbirleriyle örtüştükleri tespit edildi. Sonuç olarak, bu çalı̧̧ma ile sitopatolojik tanı yönteminin köpeklerde deri tümörlerinin erken tanısında kullanılabileceği düşünülmektedir.
\end{abstract}

Anahtar sözcükler: Deri tümörü, histopatoloji, ince iğne aspirasyon biyopsisi, köpek, sitopatoloji.

\section{Introduction}

Neoplasms of the skin and its appendages are among the most frequently observed tumours in dogs. Although these tumours may develop at any age, they are more prevalent in dogs aged 6-12 years $(9,12,15)$. It has been reported that mongrel dogs, German shepherds,
Poodles and Boxers are predisposed to skin tumours. Although skin neoplasms may occur throughout the body, they are mostly located in the head, back, extremities and tail $(2,7,15)$.

FNAB is a minimally invasive, quick and inexpensive method $(5,13,14,21)$. This examination is

\footnotetext{
* This study was prepared partly from the $\mathrm{PhD}$ thesis of the corresponding author.
} 
commonly used for cutaneous tumours, mammary gland tumours and palpable lesions. Cytological examination can be used for the diagnosis of various types of disease $(7,11,30,31)$. FNAB technique is not commonly used for diagnosis of canine skin tumours in Turkey.

The aim of this study was to compare the accuracy and the efficiency of a cytology technique with histopathological diagnosis, and to examine the sensitivity of cytology in the diagnosis of canine skin tumours.

\section{Materials and Methods}

Forty-three dogs of varying age, breed, and sex, with a suspected skin tumour were referred to the clinics of the Department of Surgery of Ankara University, Faculty of Veterinary Medicine, and the clinics of private veterinary practitioners in Ankara, between 2009 and 2012.

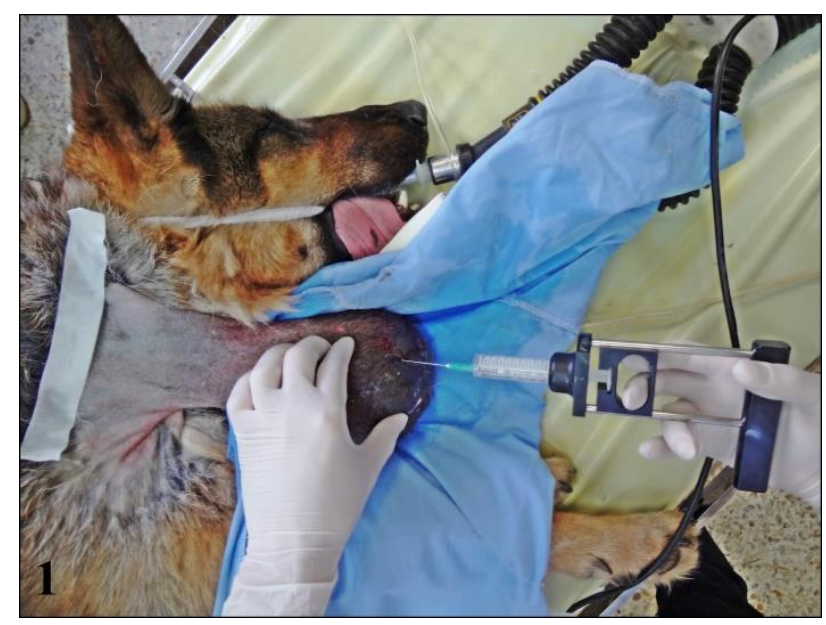

Figure 1. Cytology examination from dogs which had been mildly sedated preoperatively.

Şekil 1. Preoperatif dönemde sedasyondaki köpekten sitolojik örnek alınması.

The aspirated samples for cytology examination using FNAB technique were taken from dogs which had been mildly sedated preoperatively (Figure 1). For cytological examinations a 20-Gauge needle attached to a $10 \mathrm{ml}$ syringe with FNAB technique was used by the pathologist. For aspiration; after the mass is stabilized between fingers needle is inserted in the periphery of the mass, negative pressures were applied with plunger of syringe at least 3-4 times at different angles of the tumors, syringe moved back and aspirate spouted onto the slides and smeared. Four smears were prepared for each tumor, after air-dried smears were stained with May-Grünwald Giemsa (MGG). All slides were examined under light microscope with 40x and 100x objectives. The tissue samples were surgically removed from the same animals under general anaesthesia and they were fixed in $10 \%$ neutral formalin solution. Then, the tissue samples were routinely processed and embedded in paraffin. Sections of $5 \mu \mathrm{m}$ thickness were cut from the paraffin blocks and stained with H\&E. All slides were examined under a light microscope and tumours were classified according to the WHO standards and the Goldschmitd et al. (8) classification scheme.

\section{Results}

The distribution of the number of tumours for the canine breeds was as follows: $14(32,6 \%)$ Terriers, 14 (32,6\%) mongrels, 4 (9,3\%) Golden retrievers, 3 (6,9\%) Cocker Spaniels, $3(6,9 \%)$ Boxers, 2 (4,7\%) Anatolian shepherd dogs, 2 (4,7\%) Huskys and 1 (2,3\%) German Shepherd dogs (Table I). Of the dogs diagnosed with skin tumour, the youngest was 6 months old and the oldest was 16 years of age. The localisation of skin tumours was $12(27,9 \%)$ in the head, $9(20,9 \%)$ in the trunk, $8(18,6 \%)$ in the perianal region, $6(14 \%)$ in the extremities, $4(9,3 \%)$ in the neck, $3(7 \%)$ in the tail and 1 $(2,3 \%)$ in the inguinal region. It was determined that the age group, in which skin tumours were most frequently encountered in dogs was 8-15 years. Twenty-nine $(67,4 \%)$ of the dogs were male and $14(32,6 \%)$ were female.

Macroscopic analysis: All of the biopsy samples taken throughout the study period were covered with skin. The majority of the tumours showed a hard or elastic consistency, and the cut surface was brown or dark-brown and multilobed. Some of the tumours had cystic structures or necrotic areas.

Cytopathological findings: General cytopathological examination revealed the presence of necrotic cell debris and inflammatory cells, including degenerated neutrophil leukocytes, lymphocytes and macrophages in cases presented with macroscopically skin ulceration. Red-pink coloured necrotic material and mucus were observed in the background of the preparations. In cases with malign characteristics, clusters of cells with anisocytosis, anisokaryosis and hyperchromasia were observed and also, some nuclear anomalies were identified such as double nucleus, giant nucleus, mitotic figures and abnormal chromatin structures. Cytopathological diagnosis determined, that $30(69,76 \%)$ were malignant epithelial tumors, $5(11,62 \%)$ benign epithelial tumors, 6 $(13,95 \%)$ suspect epithelial tumors and $2(4,65 \%)$ were few malignant epithelial tumors (Table 1).

Cytopathological examination demonstrated; small uniform and often cuboidal basal epithelial cells were organised clusters, cords or ribbons in shape of bunch of grapes. The cells with small amount of basophilic cytoplasm; round, small and dark-coloured nucleus contained dense chromatin (Figure $2 \mathrm{~A}$ ) (case $\mathrm{n}^{0} 11,14$, 18, 21, 22, 32 and 34). Uniform squamous epithelial cells with a light coloured basophilic and granular cytoplasm and an oval, hyperchromatic nucleus, were 
Table 1. Signalment, histopathological and cytopathological analysis of dogs included in the present study. Tablo 1. Çalışmayı oluşturan köpeklere ait bilgiler ile histopatolojik ve sitopatolojik veriler.

\begin{tabular}{|c|c|c|c|c|c|c|}
\hline Case $n^{\circ}$ & Breed & Age & Sex & Localisation & Cytopathological type & Histopathological type \\
\hline 1 & Terrier & 12 & M & Neck & Malignant epithelial tumor & Sweat gland carcinoma \\
\hline 2 & Anatolian shepherd dog & 9 & M & Neck & Benign epithelial tumor & Sweat gland adenoma \\
\hline 3 & Mongrel & 14 & M & Trunk & Suspect epithelial tumor & Sebaceous gland epithelioma \\
\hline 4 & Terrier & 15 & $\mathrm{~F}$ & Trunk & Malignant epithelial tumor & Squamous cell carcinoma \\
\hline 5 & Terrier & 14 & $\mathrm{~F}$ & Head & Suspect epithelial tumor & Sebaceous gland epithelioma \\
\hline 6 & Mongrel & 5,5 & M & Trunk & Malignant epithelial tumor & Sweat gland carcinoma \\
\hline 7 & Mongrel & 9 & M & Trunk & Malignant epithelial tumor & Sweat gland carcinoma \\
\hline 8 & Terrier & 15 & $\mathrm{~F}$ & Trunk & Malignant epithelial tumor & Squamous cell carcinoma \\
\hline 9 & Terrier & 16 & M & Extremities & Malignant epithelial tumor & Sebaceous gland carcinoma \\
\hline 10 & Terrier & 13 & M & Perianal & Malignant epithelial tumor & Squamous cell carcinoma \\
\hline 11 & Boxer & 12 & M & Extremities & Few malignant epithelial cells & Basal cell carcinoma \\
\hline 12 & Terrier & 14 & M & Perianal & Malignant epithelial tumor & Hepatoid gland carcinoma \\
\hline 13 & Terrier & 15 & M & Perianal & Malignant epithelial tumor & Hepatoid gland carcinoma \\
\hline 14 & Golden Retriever & 2 & M & Head & Malignant epithelial tumor & Basal cell carcinoma \\
\hline 15 & Mongrel & 12 & M & Extremities & Suspect epithelial tumor & Sweat gland adenoma \\
\hline 16 & Cocker Spaniels & 12 & M & Tail & Benign epithelial tumor & Hepatoid gland adenoma \\
\hline 17 & Terrier & 10 & M & Inguinal region & Malignant epithelial tumor & Squamous cell carcinoma \\
\hline 18 & Golden Retriever & 3 & $\mathrm{~F}$ & Extremities & Malignant epithelial tumor & Basal cell carcinoma \\
\hline 19 & Mongrel & 0.8 & M & Trunk & Malignant epithelial tumor & Squamous cell carcinoma \\
\hline 20 & Terrier & 14 & $\mathrm{~F}$ & Head & Benign epithelial tumor & Sebaceous gland epithelioma \\
\hline 21 & Mongrel & 5 & $\mathrm{~F}$ & Head & Malignant epithelial tumor & Basal cell carcinoma \\
\hline 22 & Husky & 6 & M & Head & Malignant epithelial tumor & Basal cell carcinoma \\
\hline 23 & Terrier & 15 & M & Head & Malignant epithelial tumor & Squamous cell carcinoma \\
\hline 24 & Cocker Spaniels & 10 & $\mathrm{~F}$ & Perianal & Malignant epithelial tumor & Hepatoid gland carcinoma \\
\hline 25 & Boxer & 8 & M & Neck & Suspect epithelial tumor & Sweat gland carcinoma \\
\hline 26 & Mongrel & 11 & M & Tail & Malignant epithelial tumor & Squamous cell carcinoma \\
\hline 27 & Mongrel & 10 & M & Perianal & Benign epithelial tumor & Hepatoid gland adenoma \\
\hline 28 & Mongrel & 7 & M & Perianal & Suspect epithelial tumor & Hepatoid gland adenoma \\
\hline 29 & Golden Retriever & 0.6 & M & Head & Suspect epithelial tumor & Papilloma \\
\hline 30 & Mongrel & 10 & $\mathrm{~F}$ & Extremities & Malignant epithelial tumor & Squamous cell carcinoma \\
\hline 31 & Mongrel & 0.6 & $\mathrm{~F}$ & Head & Benign epithelial tumor & Papilloma \\
\hline 32 & Terrier & 7 & M & Trunk & Malignant epithelial tumor & Basal cell carcinoma \\
\hline 33 & Mongrel & 11 & M & Perianal & Malignant epithelial tumor & Hepatoid gland carcinoma \\
\hline 34 & Mongrel & 7 & $\mathrm{~F}$ & Extremities & Malignant epithelial tumor & Basal cell carcinoma \\
\hline 35 & Husky & 15 & M & Head & Malignant epithelial tumor & Squamous cell carcinoma \\
\hline 36 & Mongrel & 8 & $\mathrm{~F}$ & Tail & Malignant epithelial tumor & Squamous cell carcinoma \\
\hline 37 & Terrier & 13 & M & Perianal & Malignant epithelial tumor & Hepatoid gland carcinoma \\
\hline 38 & Anatolian shepherd dog & 10 & $\mathrm{~F}$ & Trunk & Malignant epithelial tumor & Malignant pilomatricoma \\
\hline 39 & German Shepherd dog & 10 & $\mathrm{~F}$ & Neck & Malignant epithelial tumor & Sweat gland carcinoma \\
\hline 40 & Cocker Spaniels & 9 & M & Head & Malignant epithelial tumor & Sebaceous gland carcinoma \\
\hline 41 & Golden Retriever & 0.6 & $\mathrm{~F}$ & Head & Malignant epithelial tumor & Squamous cell carcinoma \\
\hline 42 & Terrier & 13 & M & Perianal & Malignant epithelial tumor & Hepatoid gland carcinoma \\
\hline 43 & Boxer & 8 & M & Head & Few malignant epithelial cells & Squamous cell carcinoma \\
\hline
\end{tabular}

n: Number, M: Male, F: Female. 


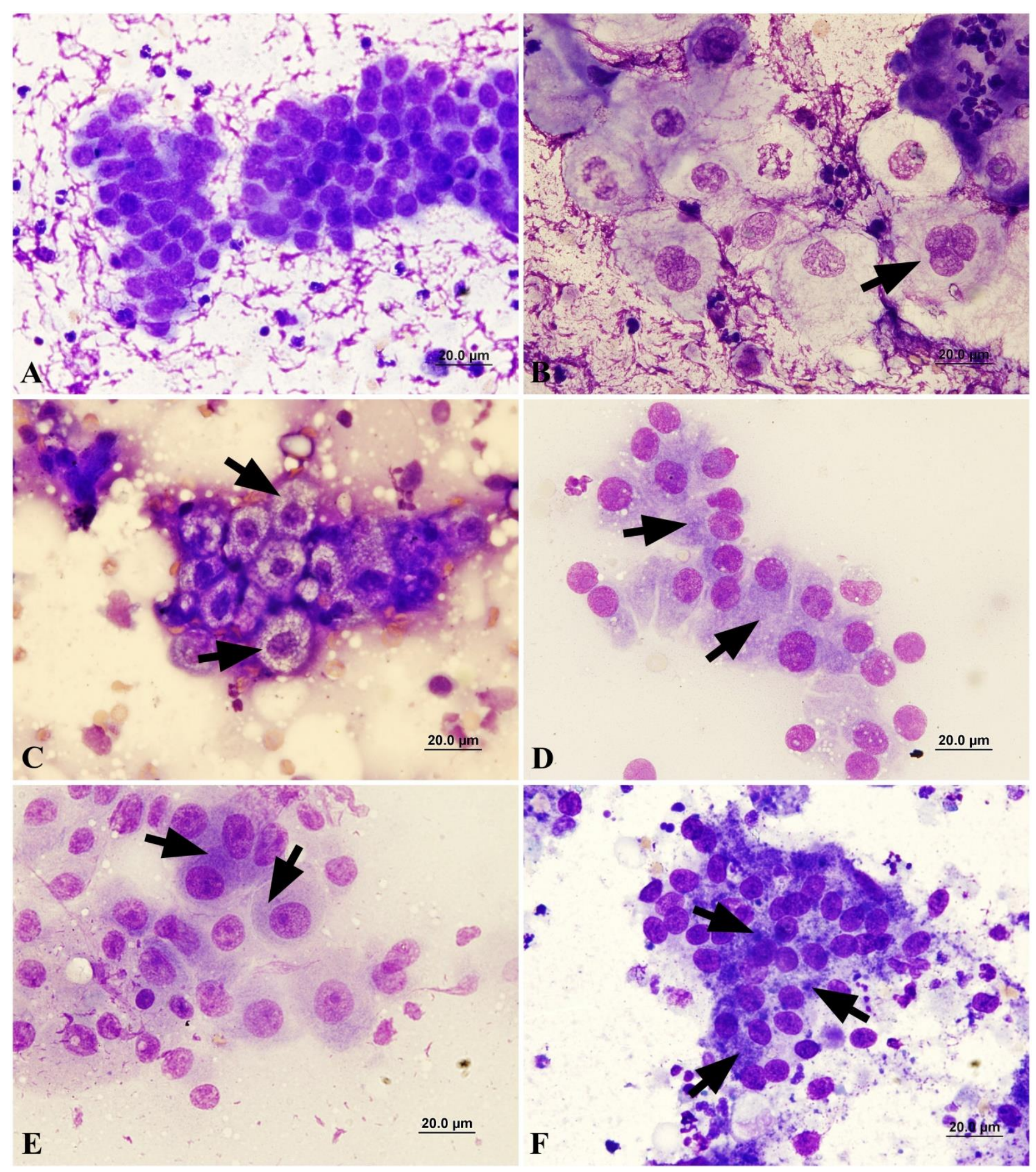

Figure 2. A. Aspirate from a basal cell tumor (Case $\left.n^{0} 14\right)$, cells with a small amount of pale red cytoplasm, (MGG). B. Aspirate from

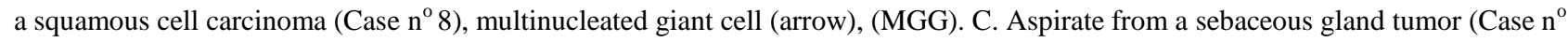
40), epithelial cells characterized by basophilic cytoplasm containing a variable number of vacuoles (arrows), (MGG). D. Aspirate from a sweat gland tumor (Case $\mathrm{n}^{\mathrm{o}} 7$ ), the cells are well differentiated and have granular cytoplasm (arrows), (MGG). E. Aspirate from a hepatoid gland adenoma (Case $\mathrm{n}^{\circ}$ 16), large hepatoid cells showing a moderate to large amount of amphophilic, granular cytoplasm (arrows), (MGG). F. Aspirate from a malignant pilomatricoma (Case $n^{\circ} 38$ ), small basaloid epithelial tumor cells show basophilic calcium accumulations in cytoplasm (arrows), (MGG).

Şekil 2. A. Bazal hücreli kanser, dar ve solgun kırmızı sitoplazmalı hücreler (Olgu n ${ }^{\circ}$ 14), (MGG). B. Yassı hücreli kanser (Olgu $\mathrm{n}^{\mathrm{o}}$ 8), çok çekirdekli dev hücresi (ok), (MGG). C. Sebaseöz bez tümörü (Olgu no 40), çok sayıda vakuollerinin olduğu dar bazofilik sitoplazmalı epitel hücreleri (oklar), (MGG). D.Ter bezi tümörü $\left(\mathrm{Olgu} \mathrm{n}^{\circ} 7\right)$, iyi diferensiye ve granüler sitoplazmalı epitel hücreleri (oklar), (MGG). E. Hepatoid bez adenomu (Olgu n $\left.{ }^{\circ} 16\right)$, büyük ve granüler sitoplazmalı hepatoid tümör hücreleri (oklar), (MGG). F. Malignant pilomatrikoma (Olgu n $\left.{ }^{\circ} 38\right)$, küçük bazaloid epitel tümör hücre sitoplazmalarında kalsiyum birikimi (oklar), (MGG). 

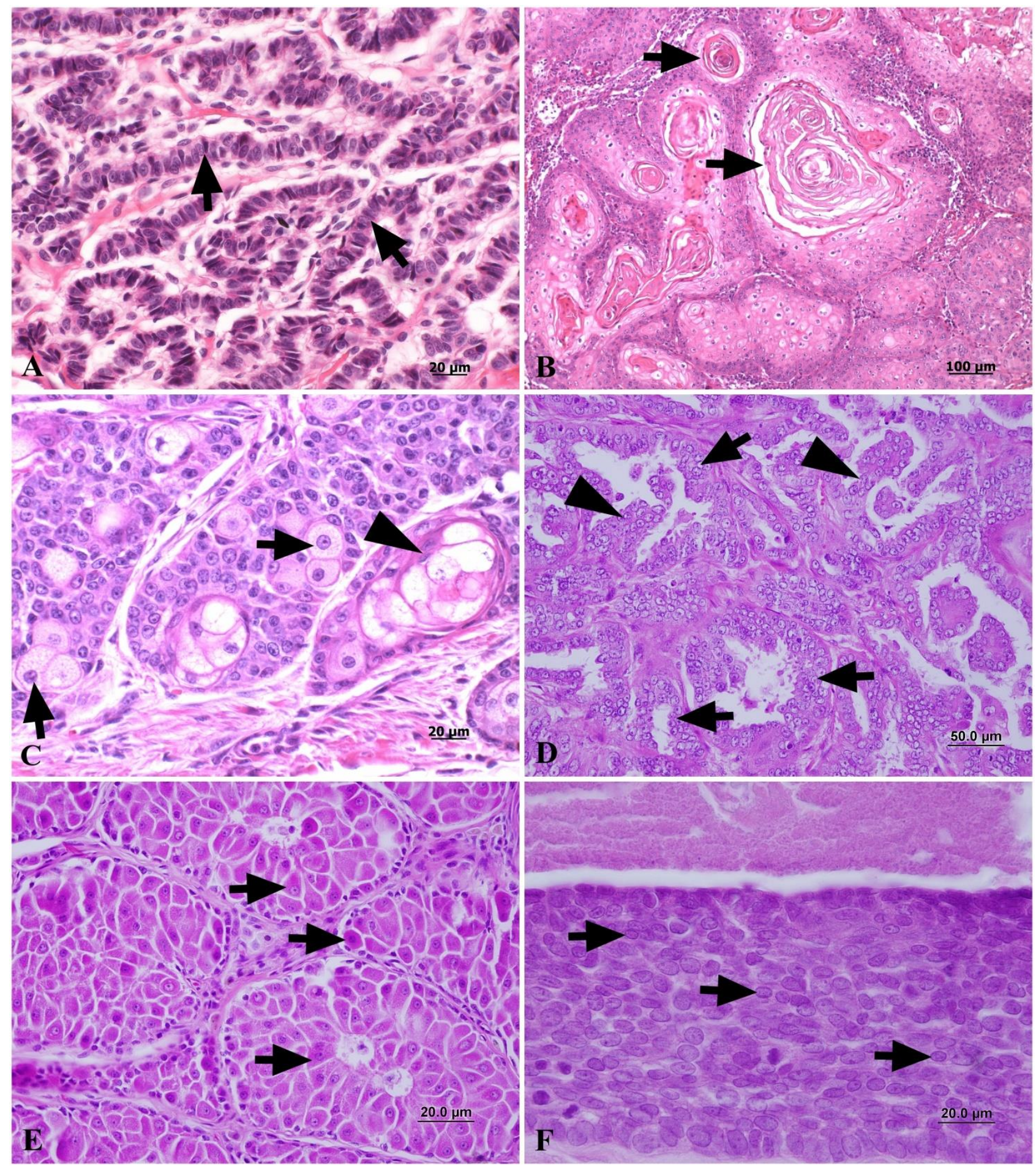

Figure 3. A. Basal cell carcinoma (Case $\mathrm{n}^{\circ} 14$ ), showing classic feature of nuclear palisading (arrows), (H\&E). B. Squamous cell carcinoma (Case $\mathrm{n}^{\circ} 8$ ), formation of a distinct keratin (arrows), (H\&E). C. Sebaceous gland tumor (Case $\mathrm{n}^{\circ} 40$ ), oval hyperchromatic nucleus and a marked nucleolus (arrows), ducts of varying width and metaplasia (arrowhead), (H\&E). D. Sweat gland tumor (Case $\mathrm{n}^{\circ}$ 7), single or multilayer of lining cells (arrows) and show invaginations of the epithelium into the glandular lumina (arrowheads), (H\&E) E. Hepatoid gland adenoma (Case $\mathrm{n}^{\mathrm{o}} 16$ ), hepatocyte-like cells appearance of neoplastic tissue (arrows), (H\&E). F. Malignant pilomatricoma (Case $\mathrm{n}^{\circ} 38$ ), small epithelial cells showing nuclear pleomorphism (arrows), (H\&E).

Şekil 3. A. Bazal hücreli karsinom (Olgu n $\left.{ }^{\circ} 14\right)$, çit şeklinde dizilim gösteren bazal epitel hücreleri (oklar), (HE). B. Yassı hücreli kanser (Olgu n ${ }^{\circ}$ 8), keratin adacıkları (oklar), (HE). C. Sebaseöz bez tümörü (Olgu n $\left.{ }^{\circ} 40\right)$, oval hiperkromatik çekirdek ve belirgin çekirdekcik (oklar), akıtıcı kanalda metapilazik değişiklik (ok) (HE). D. Ter bezi tümörü (Olgu n ${ }^{\circ}$ 7), tek veya çift sıra dizilimli (oklar) ve yer yer lumene doğru uzantılar yapmış ter bezi epiteli (okbaşları), (HE). E. Hepatoid bez adenomu (Olgu n $\left.{ }^{\circ} 16\right)$, hepatosit benzeri epitel hücrelerinin oluşturduğu neoplastik yapı (oklar), (HE). F. Malignant pilomatrikom (Olgu $\mathrm{n}^{\circ} 38$ ), çekirdeklerde pleomorfizim gösteren dar sitoplazmalı, küçük bazaloid epitel hücreleri (oklar), (HE). 
organised either individually or in groups (Case $n^{\circ} 31$ ). Anaplastic squamous epithelial cells appear solitary or in groups, the cells with abundant and light bluish cytoplasm. Some cells show light pink color keratin debris in cytoplasm. Central or eccentric nucleus were large and polymorphous. Some cells were presented with multinucleate giant shape (Figure 2B) $\left(\right.$ Case $^{\circ}$ 4, 8, 10, 17, 19, 23, 26, 30, 35, 36, 41 and 43). Atypical epithelial cells of sebaceous glands were organised in clumps and contained bubble-like cytoplasmic vacuoles. The nucleus of these cells were small, hyperchromatic and mostly located in the centre of the cell (Case $n^{\circ} 9$ and 40), among these cells small basaloid cells were observed (Case $n^{\circ}$ 20) (Figure 2C). Clusters of epithelial tumour cells were observed to have been organised either tubularly-like or in groups formations. The cytoplasm was slightly granular and of basophilic colour (Figure 2D) (Case $\mathrm{n}^{\mathrm{o}} 1$, 2, 6, 7 and 39). Aspirat from perianal region show; uniform cells with a broad basophilic cytoplasm and a large round nucleus (Case $n^{\circ} 16$ and 27). Large and round atypical cells that were organised in groups and had a broad, slightly basophilic and granular cytoplasm were detected. The nuclei of these cells were large, round and lace-like, and contained dense chromatin. Some cells had two or three nuclei (Figure 2E) (Case $n^{\circ} 12,13,24,33$, 37 and 42). Tight cell clusters with basaloid cells showed; generally basophilic and broad cytoplasm, usually uniform round or oval hyperchromatic granular nucleus were seen. Between the tumour cells and in the cytoplasm, there was a large amount of basophilic calcium deposits with rough granules (Figure $2 \mathrm{~F})\left(\operatorname{dog} \mathrm{n}^{\circ}\right.$ 38). On the other hand, six tumor $\left(\right.$ Case $^{\circ}{ }^{3} 3,5,15,25,28$ and 29) of all cases were incorrect or no diagnosed because of, false application of FNAB, lots blood and inadequate tumor cells.

Histopathological findings: The general histopathological examination revealed the presence of ulcerations in the stratified squamous epithelium in most of the samples. The cornified layer had thickened and the thickening was associated with hyperkeratosis. Inflammatory cell infiltrations composed of neutrophil leukocytes, lymphocytes and macrophages were observed in these regions. Furthermore, oedematous and haemorrhagic areas were evident.

Histopathological examination showed that: small and partly atypical basal cells, which had a basophilic appearance, narrow cytoplasm and round nucleus containing dense chromatin, were observed to have been organised into dermis and subcutis as fence or cords form (Figure 3A) (Case $n^{\circ} 11,14,18,21,22,32$ and 34). The papillomatous proliferation of epidermis was prominent and forming acanthotic extensions into the dermis, hyperkeratosis was markedly, the cells of tumors were mildly pleomorphic. And also keratohyalin granules were observed in epidermal tumor cells (Case $n^{\circ} 29$ and 31).
The round pleomorphic cells of the stratum spinosum, which had a broad cytoplasm and a large, oval nucleus, were observed to be irregularly scattered in groups throughout the stroma, which was composed of large connective tissue cells. In the centre of these cell groups, parakeratotic keratin islets (parakeratotic globe-cornes) composed of stratum spinosum cells that had undergone karyorrhexis or hyperkeratotic keratin islets (hyperkeratotic globe-cornes) were observed (Figure 3B) (Case $^{\circ}$ 4, 8, 10, 17, 19, 23, 26, 30, 35, 36, 41 and 43). Atypical sebaceous gland epithelial cells were surrounded by fine connective tissue trabeculae and contained a vacuolar cytoplasm, an oval hyperchromatic and vesicular nucleus and a marked nucleolus. These cells were surrounded by atypical epithelial cells with a narrow cytoplasm. Between these structures were ducts of varying width and squamous metaplasias (Figure 3C) (Case $\mathrm{n}^{\mathrm{O}}$ 3, 5, 9, 20 and 40). In dermis and subcutis neoplastic glandulary foci were seen between fibrous capsule. The tumor cells were large, polygonal and with eosinophilic cytoplasm (Case $n^{\circ} 2$ and 15). Lumen of the sweat glands had significantly enlarged, with the epithelium of some of the glands being two or threelayered, some having flattened and acquired a cystic appearance (Figure 3D) (Case $n^{\circ} 1,6,7,25$ and 39). Hepatocyte-like polyhedral epithelial cells of the perianal glands had a markedly eosinophilic cytoplasm, a large, oval and vesicular nucleus and a hyperchromatic nucleolus organised in the form of islets over a broad area (Case $\mathrm{n}^{0}$ 16, 27 and 28). In malignant cases, hepatocyte-like anaplastic cells with an eosinophilic cytoplasm were determined to have been distributed over a broad area (Figure 3E) (Case $n^{\circ} 12,13,24,33,37$ and 42). In malignant pilomatricoma, keratin islets, which formed broad areas of lamellation in the dermis and were surrounded by anaplastic, polygonal shaped basal cells with a hyperchromatic oval nucleus and narrow cytoplasm that were organised in the form of cords (Figure 3F) (Case $\left.n^{\circ} 38\right)$.

In 6 out of the 43 cases examined, the cytopathological and histopathological diagnoses disagreed. In $86,05 \%$ of the cases, cytopathological examination enabled accurate early diagnosis.

\section{Discussion and Conclusion}

Many studies conducted in Turkey and in other countries have shown that skin tumours are the second most frequently encountered neoplasms of dogs after tumours of the mammary glands $(3,6,9,12,15,24,29)$. Merlo et al. (20) reported that $48.9 \%$ of skin tumours are malignant, while $51.1 \%$ are benign. In a study carried out on 174 dogs, Kaldrymidou et al. (15) determined that $46.6 \%$ of the tumours were malignant and $53,4 \%$ were benign. Sanja et al. (26) indicated that of the 211 skin tumours they examined, 53,55\% were malignant and 
$46,44 \%$ were benign. In the present study, of the 43 tumours detected, $72,1 \%$ were malignant and $27,9 \%$ were benign. In another study on skin tumours, Ghisleni et al. (7) reported the accuracy of cytopathological diagnosis as $83,2 \%$. The same rate was calculated as $90,9 \%$ by Macneil (17). In the present study, out of the 43 cases examined cytopathologically, 6 were misdiagnosed. The diagnosis of $86,05 \%$ of the cases was confirmed by histopathological examination.

In previously conducted research, it has been determined that in dogs, males are more susceptible to skin tumours than females $(15,16,18)$. The findings obtained in the present study conformed with those reports in literature as, of the dogs diagnosed with skin tumour, $67,4 \%$ were male and $32,6 \%$ were female.

The mean age at which skin tumours are observed was reported as 7,5 years for dogs by Sharif (28) whilst Lakatos et al. (16) sated that skin tumours are frequently encountered in dogs aged 4-6 years. Pakhrin et al. (24) determined this age to be 8,3 years. In the present study, an increased prevalence of skin tumours was determined in dogs aged $8-15$ years.

Of the dog breeds examined, the German Shepherd, Rottweiler and Spanish Cocker Spaniel in particular have been reported to be more susceptible to skin tumours ( 9 , 15, 16). The present study demonstrated that skin tumours were frequently encountered in Terriers and mongrel dogs, but were occasionally encountered in the Husky and German Shepherd dog. To the best of our knowledge, there are no reports in literature related to malignant pilomatricoma $\left(\mathrm{n}^{\circ} 38\right)$ and sweat gland adenoma $\left(\mathrm{n}^{\mathrm{o}} 2\right)$ detected in the Anatolian shepherd dog as in the present study.

Skin tumours are most frequently located in the head, neck, anal region and extremities (9, 20, 28, 29). The findings obtained for tumour localisation in the present study were in agreement with those reported in previous research. Nontheless, skin tumours occurring in rare localisation sites were also observed in this study, with a tumour located in the inguinal region in case of $\mathrm{n}^{\mathrm{o}} 17$.

The assessment of the general distribution of the skin tumours revealed that squamous cell carcinoma, basal cell carcinoma, papilloma and hepatoid gland tumours occurred more frequently than other skin tumours $(23,24,28)$. In the present study, $27,9 \%$ of the tumours detected were squamous cell carcinoma, 20,9\% hepatoid gland tumours, 16,3\% basal cell carcinoma, $16,3 \%$ sweat gland tumours, $11,6 \%$ sebaceous gland tumours and 4,7\% papilloma. Furthermore, the diagnosis of the less frequently observed malignant pilomatricoma $\left(n^{\circ} 38\right)$ in a dog, at the rate of $2,3 \%$, was considered significant.

Basal cell carcinomas mainly occur in the head and neck regions $(9,23,28)$. However, in the present study, of these tumours, 3 were detected in the head, 3 in the extremities and 2 in the trunk. The mean age at which squamous cell carcinomas are most frequently observed has been reported as 9,5 years for dogs. This type of skin tumour is mostly located in the head, trunk and extremities in $\operatorname{dogs}(9,23,24,26)$. In the present study, the mean age of dogs diagnosed with squamous cell carcinoma was calculated as 10,1 years, with the age of the 1 female in that group being 6 years.

Tumours of the sebaceous glands are highly prevalent in dogs. The incidence of this type of skin tumour increases between 8 and 12 years of age $(9,25$ $28)$. In contrast to the available literature reports, the 3 cases diagnosed in the present study were observed to have occurred in older dogs (14 years of age). This type of tumour is generally located in the head $(9,26,27)$. Of the 3 cases observed in the present study, that 2 determined to be located in the ear conforms with previous research. However, one case was detected in the sacral region, which is an infrequent site of localisation for this tumour. Sebaceous carcinomas are rarely encountered in dogs. They generally occur in 8 to 12 year-old animals. Throughout the study period, only 2 carcinoma cases were diagnosed. As one of the cases $\left(\mathrm{n}^{\circ}\right.$ 9) was determined in an animal aged 16 years, it was considered that this type of tumour could also be detected in elderly dogs. Terriers and Poodles are reported to be more susceptible to malignant pilomatricoma $(4,10,19)$. In the present study, this type of tumour was only detected in the back of a 10-year-old Anatolian shepherd $\operatorname{dog}\left(\mathrm{n}^{\mathrm{o}} 38\right)$. Hepatoid gland adenomas are neoplasms that occur in dogs of all ages. Carcinomas are encountered more frequently in dogs aged $8-12$ years $(1,9,22,28)$. In the present study, of the 3 animals diagnosed with hepatoid gland adenoma, the youngest was 7 years old and the oldest was 12 years old. Cases of carcinoma were more prevalent in animals aged 10-14 years and in Terriers.

In conclusion, although cytopathological examination has not yet come into extensive use in veterinary medicine for the diagnosis of skin tumours, the results obtained in the present study suggest that cytopathology is a practical tool for the early diagnosis of skin neoplasms. Cytopathology is advantageous for the diagnosis of skin tumours in that it is easily applied and produces results more rapidly at a much lower cost and with minimal harm to the patient. Also, the lesions in skin tumours are readily accessible and so generally, cytological material is available in an amount sufficient for diagnosis.

Therefore, it is suggested that cytopathology can be used for the diagnosis of skin tumours in dogs and should be confirmed by histopathology. It is considered that this study will constitute a reference for future studies conducted by academicians and private veterinary practitioners. 


\section{Acknowledgement}

This study was supported by Management of Scientific Research Projects of Harran University (Project number: 886). The authors would like to thank Ankara University, Faculty of Veterinary Medicine, Department of Surgery for providing the specimens.

\section{References}

1. Berrocal A, Vos JH, Van Den Ingh Tsgam, et al. (1989): Canine perianal tumours. Zentralbl Veterinarmed A, 36, 739-749.

2. Bettini G, Morini M, Campagna F, et al. (2005): True grit: The tale of a subcutaneous mass in a dog. Vet Clin Pathol, 34, 73-75.

3. Bronden LB, Nielsen SS, Toft N, et al. (2010): Data from the Danish veterinary cancer registry on the occurrence and distribution of neoplasms in dogs in Denmark. Vet Rec, 166, 586-90.

4. Carroll EE, Fossey SL, Mangus LM, et al. (2010): Malignant pilomatricoma in 3 dogs. Vet Pathol, 47, 937943.

5. Daskalopoulou D, Maounis N, Kokalis G, et al. (1993): The role of fine needle aspiration cytology in the diagnosis of primary skin tumors. Arch Anal Cytol Path, 41, 75-81.

6. Dobson JM, Samuel S, Milstein H, et al. (2002): Canine neoplasia in the UK: estimates of incidence rates from a population of insured dogs. Small Anim Pract, 43, 240246.

7. Ghisleni G, Roccabianca P, Ceruti R, et al. (2006): Correlation between fine-needle aspiration cytology and histopathology in the evaluation of cutaneous and subcutaneous masses from dogs and cats. Vet Clin Pathol, 35, 24-30.

8. Goldschmidt MH, Dunstan RW, Stannard AA, et al. (1998): Histological classification of epithelial and melanocytic tumors of the skin of domestic animals. In: Schulman FY (ed.). WHO international histological classification of tumors of domestic animals, Armed Forces Institute of Pathology, Washington.

9. Goldschmidt MH, Hendrick MJ (2002): Tumors of the skin and soft tissues. In: Meuten DJ (ed.). Tumors in Domestic Animals. pp. 45-117, Iowa State Press, Iowa.

10. Goldschmidt MH, Thrall DE, Jeglum KA, et al. (1981): Malignant pilomatricoma in a dog. J Cutan Pathol, 8, 375 381.

11. Griffiths GL, Lumsden JH, Valli V (1984): Fine-needle aspiration cytology and histologic correlation in canine tumors. Vet Clin Pathol, 13, 13-17.

12. Gulcubuk A, Gurel A (2003): 1995-2000 yılları arasinda İstanbul'da saptanan köpek tümörleri. Istanbul Univ Vet Fak Derg, 29, 83-91.

13. Hall RL, Macwilliams PS (1988): The cytologic examination of cutaneous and subcutaneous masses. Semin Vet Med Surg (Small Anim), 3, 94.

14. Haziroglu R, Yardimci B, Aslan S, et al. (2010): Cytological evaluation of canine mammary tumours with fine needle aspiration biopsy technique. Revue Méd Vét, 161, 212-218.

15. Kaldrymidou $\mathbf{H}$, Leontides $\mathbf{L}$, Koutinas SF, et al. (2002): Prevalence, distribution and factors associated with the presence and the potential for malignancy of cutaneous neoplasms in 174 dogs admitted to a clinic in Northern Greece. J Vet Med A Physiol Pathol Clin Med, 49, 87-91.

16. Lakatos I, Baba AI, Catoi C, et al. (2008): Spontaneous skin tumors in dogs and cats, squamous carcinoma. Bulletin UASVM, 65, 51-54.

17. Macneill AL (2011): Cytology of canine and feline cutaneous and subcutaneous lesions and lymph nodes. Top Companion Anim Med, 26, 62-76.

18. Madewell BR, Theilen GH (1987): Tumors of the skin and subcutaneous tissues. Veterinary Cancer Medicine, Lea \& Febiger, Philadelphia, 238-281.

19. Masserdotti C, Ubbiali FA (2002): Fine needle aspiration cytology of pilomatricoma in three dogs. Vet Clin Pathol, 31, 22-25.

20. Merlo DF, Rossi L, Pellegrino C, et al. (2008): Cancer incidence in pet dogs: Findings of the animal tumour registry of Genoa, Italy. J Vet Int Med, 22, 976-984.

21. Morrison WB, Denicola DB (1993): Advantages and disadvantages of cytology and histopathology for the diagnosis of cancer. Semin Vet Med Surg, 8, 222-227.

22. Nielsen SW, Aftosmis J (1964): Canine perianal gland tumors. J Am Vet Med Assoc, 144, 127.

23. Nielsen SW, Cole CR (1960): Cutaneous epithelial neoplasms of the dog, a report of 153 cases. Amer J Vet Res, 21, 931.

24. Pakhrin B, Kang MS, Bae IH, et al. (2007): Retrospective study of canine cutaneous tumors in Korea. $\mathrm{J}$ Vet Sci, 8, 229-236.

25. Rothwell TLW, Howlett CR, Middleton DJ, et al. (1987): Skin neoplasms of dogs in Sydney. Austr Vet J, 64, 161.

26. Sanja AK, Kukolj V, Marinkovic D, et al. (2005): Retrospective study of canine epithelial and melanocytic tumors. Acta Veterinaria (Beograd), 55, 319-326.

27. Scott DW, Anderson WI (1990): Canine sebaceous gland tumors: A retrospective analysis of 172 cases. Canine Pract, 15, 24-27.

28. Sharif MAM (2006): Epidemiology of skin tumors entities according to the new WHO classification in dogs and cats. VVB, Laufersweiler Verlag, Giessen, Germany.

29. Vascellari M, Baioni E, Ru G, et al. (2009): Animal tumour registry of two provinces in northern Italy: Incidence of spontaneous tumours in dogs and cats. BMC Vet Res, 5, 39.

30. Wellman ML (1990): The cytologic diagnosis of neoplasia. Vet Clin North Am Small Anim Prac, 20, 919937.

31. Yildirim F, Gurel A (2012): Comparison between cytological and histopathological evaluations of canine mammary tumours. Revue Méd Vét, 163, 116-122.

Geliş tarihi: 01.07.2015 / Kabul tarihi: 13.10.2015
Address for correspondence:
Dr. Nihat YUMUŞAK
University of Harran,
Faculty of Veterinary Medicine,
Department of Pathology,
Eyyubiye-Şanliurfa/Turkey
e-mail:nihatyumusak@harran.edu.tr 